\title{
EFFECT OF EXPOSURE MEDIA, ENVIRONMENTAL PERFORMANCE AND INDUSTRIAL TYPE ON CARBON EMISSION DISCLOSURE
}

\author{
FENNY NOVIA AULIA ULFA, HUSNAH NUR LAELA ERMAYA \\ Universitas Pembangunan Nasional Veteran Jakarta, Jakarta, Indonesia \\ *Email: fennyaulia17@gmail.com
}

\begin{abstract}
The purpose of this research is to test the influence of Media Exposure, Environmental Performance And Type of Industry to Carbon Emission Disclosure. The independent variable in this research is Media Exposure measured using dummy variables, Environmental Performance is measured using an ordinal And Type of Industry is measured using dummy variables. Carbon Emission Disclosure as the dependent variable is measured using a checklist that was adopted from research Choi et al. The population of this research is nonfinancial companies that listed in the year 2014-2016. By using purposive sampling method and obtained a total sample of 36 companies per year. Methods of analysis of this research include statistic descriptive analysis, test classic assumptions, hypothesis testing and multiple linear. Results from this study indicate that Media Exposure significantly influence to the extent of carbon emission disclosure. Meanwhile, Environmental Performance and Type of Industry had no significant influence on the extent of carbon emission disclosure. Variable Carbon Emission Disclosure can be explained by the variable Media Exposure, environmental performance and the type of Industry amounted to 30\%, while the remaining $70 \%$ is influenced by the other variables which are not researched in the study.
\end{abstract} Keyword : Carbon Emission Disclosure, Voluntary Disclosure, Media
Exposure, Environmental Performance, Type of Industry

\section{INTRODUCTION}

Climate change has become the biggest environmental issue that has caught the attention of the world today. The industrial revolution that took place in England in the 18th century has fostered industrial success in the world (Ministry of Environment, 2012). This revolution has transformed the industry which was originally slow to be fast. However, behind the success in accelerating the pace of the world economy, there are unavoidable adverse effects of a decrease in 
Jurnal Ilmiah Akuntansi Universitas Pamulang - Vol. 7, No. 2, Juli 2019 - Ulfa \& Ermaya

environmental quality in line with the rapid growth of the industry, the retention of carbon and other greenhouse gases tends to increase over time (Martinez, 2005).

According to WRI (World Resource Institute) data, carbon emissions produced by countries in the world are 46 billion tons of $\mathrm{CO} 2$ per year. This fact places Indonesia as the sixth largest carbon emitter in the world at 2.05 billion tons per year (Kompas, 2014). The energy sector contributed $63 \%$, the industrial sector accounted for $3 \%$, the forestry sector and land conversion functioned at $18 \%$, the agricultural sector accounted for $13 \%$ and waste amounted to $3 \%$ of total greenhouse gases (Rosegrent et al, 2008).

The energy sector is the largest contributor to carbon emissions, with one of the cases of coal steam power plants (PLTU). Carbon emissions produced from coal-fired power plants form particles and ozone which have a negative impact on health and cause new problems, namely air pollution. The current environment has been damaged because of the pollution that can cause a decrease in the quality of the environment (Kompas, 2015).

One example of environmental degradation caused by the forestry sector and land function experts is the phenomenon of peat fires that occurred in West Aceh in the past few months which reached 69 hectares (Tribunnews, 2017). Most of the territory of Indonesia is a forest which is an oxygen producer and absorbs carbon dioxide gas (the lungs of the world). However, now it has turned into a carbon dioxide gas producing land (Ministry of Environment, 2012). The loss of carbon stocks makes Indonesia's peatlands one of the main sources of world carbon emissions. This to should be the focus of the company's attention to land management in Indonesia if the world hopes to reduce carbon emissions (Pratiwi and Sari, 2016).

One of the causes of climate change in the world is greenhouse gases produced by human activities. Fifty of the 500 largest companies listed in the world account for nearly three-quarters of the 3.6 billion metric tons of greenhouse gas (GHG) (CDP, 2013). Treatment of these issues then developed Carbon Emission Disclosure by presenting carbon generated from the company's operational activities presented in the annual report, which is expected to be able to prevent or reduce carbon emissions in Indonesia. Carbon Emission Disclosure in Indonesia is still voluntary disclosure and the practice is still rarely done by business entities.

The company is responsible for stakeholders within the company and outside the company. Thinking about the sustainable business that promotes the environment (planet) as a source of all resources, the welfare of employees and the community outside the company (people), and profit (profit) for the survival of the company.

On December 3, 2004, Indonesia as one of the countries that signed the Kyoto Protocol through Law No. 17 of 2004 in order to carry out sustainable development and participate in efforts to reduce global GHG emissions. There are 6 GHGs targeted for reduction in the Kyoto Protocol, namely carbon dioxide (CO2), methane (CH4), nitrous oxide (N2O), sulfur hexafluoride (SF6), perfluorocarbons (PFC), and hydrofluorocarbons (HFC) (Jannah, 2014). This 
Jurnal Ilmiah Akuntansi Universitas Pamulang - Vol. 7, No. 2, Juli 2019 - Ulfa \& Ermaya

research focuses on one of the GHGs, namely $\mathrm{CO} 2$ (carbon emissions) of the company which is the biggest contributor to global climate change.

\section{LITERATURE REVIEW}

\section{Legitimacy Theory}

Organizations/companies must continually ascertain whether they have operated within the norms that are upheld by society and ensure that their activities are acceptable to outsiders (legitimized) (O'Donovan, 2002). When there is a difference between the values adopted by the company and the values of society, the legitimacy of the company will be in a threatened position that can affect the company's ability to continue its business activities (Dowling and Preffer, 1975).

The company will voluntarily report its activities if management considers the public to expect such disclosure. The company is expected to be responsive to the environment around the company in operation because between the company and the community there is a social contract that is the hope of the community towards companies operating in the surrounding environment but not clearly written in legal regulations (Deegan, 2002).

Companies must report their activities on an ongoing basis that is consistent with social values. This can be done by making disclosures in company reports. These disclosures can enhance the value and image of the company so as to provide legitimate activities of the company in the eyes of the public.

\section{Stakeholder Theory}

The stakeholder concept was first developed by Freeman to explain corporate behavior and social performance (Ghomi and Leung, 2013). Stakeholders as groups or individuals who can influence or be influenced by the achievement of certain goals (Freeman, 1984). The existence of a corporation as a business entity in a place does not only interact directly with the government as a formal authority but also with many stakeholders who are stakeholders, including the local community (Lako, 2011). Stakeholders have different expectations for the company, to pursue these expectations stakeholders can put pressure on the company directly or indirectly in making environmental disclosures (Ghomi and Leung, 2013).

\section{Carbon Emission Disclosure}

Carbon emission disclosure is a disclosure to assess carbon emissions of a company and set targets for reducing carbon emissions (Cahya, 2016). At present, the company has been required to disclose the company's activities in operation. Companies can increase the value of the company by making environmental disclosures and can even reduce or eliminate the adverse effects that might occur in the company and provide benefits to the environment and society.

Carbon emission disclosure is one of the environmental disclosures included in additional reports. The government makes regulations in order to reduce carbon emissions in Indonesia. Regulations relating to this are the Presidential Regulation 
Jurnal Ilmiah Akuntansi Universitas Pamulang - Vol. 7, No. 2, Juli 2019 - Ulfa \& Ermaya

No. 61 of 2011 concerning the National Action Plan for Reducing Greenhouse Gas Emissions and Presidential Regulation No. 71 of 2011 concerning the Implementation of the National Greenhouse Gas Inventory. In line with these regulations, the government is committed to reducing emissions by $26 \%$ with its own business and 41\% with international assistance in 2020 (Tosiani, 2015).

\section{Media Exposure}

Media disclosure (media exposure) means that the company must provide information about its social responsibility and other related messages to employees, customers, and other stakeholders, and in general, to the entire community with various communication tools (Harmoni, 2011). Media plays an important role in communicating information relating to company activities to the public. Companies must be aware of the media so that the company's reputation and value are maintained. Increased media coverage of environmental and climate policies increased the role of non-governmental organizations (NGOs) such as NGOs which further signaled a shift towards public opinion (Carpenter, 2001).

\section{Environmental Performance}

Environmental performance is a result that can be measured from an environmental management system, related to the control of its environmental aspects (Ikhsan, 2009 p.308). Environmental disclosure in Indonesia is still voluntary (disclosure), companies must have an awareness of responsibility regarding environmental aspects caused by company activities. The community will demand that the company be more open in its environmental care towards its surrounding environment. Companies must be able to balance environmental issues and improve the quality of environmental performance in order to adjust community expectations.

The government made a PROPER (Corporate Performance Rating Program) an effort of the Ministry of Environment (KLH) to encourage corporate governance in environmental management through information instruments. Based on this, the company can improve its image and reputation by participating in PROPER. The company will show its concern by improving the performance of its environmental management. Information about the company's performance related to its environmental management, namely the colors given by PROPER ratings, namely gold, green, blue, red and black.

\section{Industrial Type}

The Industry is a form of economic activity that processes raw materials and/or utilizes industrial resources so as to produce goods that have higher added value or benefits, including industrial services (Industry Law No.3, 2014 article 1). The type of industry divides the industry into two groups, namely the carbonintensive industry and non-carbon intensive industry (Pratiwi and Sari, 2016). Carbon-intensive companies such as energy, transportation, materials, and utilities tend to disclose information relating to environmental aspects compared to companies that are not intensive in producing carbon from their operational activities. GICS (Global Industry Classification Standard) categorizes companies 
Jurnal Ilmiah Akuntansi Universitas Pamulang - Vol. 7, No. 2, Juli 2019 - Ulfa \& Ermaya

that most express their environmental activities as companies from the mining, manufacturing and agriculture sectors (Jannah and Muid, 2014).

\section{RESEARCH METHOD}

The method used in this study is a quantitative method. The population used in this study are all non-financial companies listed on the Stock Exchange in the 2014-2016 period, with the sampling method using Purposive Sampling with several predetermined criteria, namely, Companies that follow the Company Performance Rating Rating Program (PROPER), provide reports annual or sustainability report during 2014-2016 in a row and issued carbon emission disclosure policies (at least one policy related to carbon emissions / greenhouse gases or disclosing at least one carbon emission disclosure item).

The selection of non-financial companies in this study is because companies that produce more carbon emissions are found in non-financial industries and have more impact/influence on the surrounding environment as a result of the company's operational activities. In addition, the 2014-2016 period the Indonesian state last ratified the second period of the Kyoto Protocol in 2014.

\section{Variable Measurement}

\section{Dependent Variable}

The dependent variable used in this study is carbon emission disclosure, the measurement method used is by observing the presence or absence of an information item specified in the annual report and sustainability report using the checklist. This variable uses several items adopted from the research of Choi et al: 2013, which are constructed from information request sheets developed by the CDP (Carbon Disclosure Project) by determining five broad categories relevant to climate change and carbon emissions, namely: climate change risks and opportunities (CC/Climate Change), greenhouse gas emissions (GHG/Greenhouse Gas), energy consumption (EC/Energy Consumption), reduction of greenhouse gases and costs (RC/Reduction and Cost) and carbon emission accountability (AEC/Accountability of Emission Carbon).

If the company discloses items according to the prescribed criteria, it will be given a score of 1 , whereas if the specified item is not disclosed it will be given a score of 0 . The following is the carbon emission disclosure formula developed in this study:

$$
C E D=(\Sigma \mathrm{di} / \mathrm{M}) \times 100 \%
$$

Information :

CED : Carbon emission disclosure

$\Sigma$ di : Total score 1 obtained by the company

M : Maximum total items that can be disclosed 
Jurnal Ilmiah Akuntansi Universitas Pamulang - Vol. 7, No. 2, Juli 2019 - Ulfa \& Ermaya

Independent Variable

Media Exposure (X1)

Media Exposure is measured using a dummy variable where the value of 1 for companies that disclose information relating to carbon emissions through the website while the value of 0 is the opposite.

Environmental Performance (X2)

The PROPER assessment is given in the form of a company performance rating in improving the performance of its environmental management which consists of 5 categories and each category is represented by a color namely gold, green, red and black blue. The measurement in this study uses a scale of zero to five according to the type of color in PROPER.

Industrial Type (X3)

The type of industry in this study is measured using a dummy variable where the value of 1 for companies included in the industry is intensive in producing emissions (firms in emissions-intensive industries) which includes energy, transportation, raw materials (materials) and utilities based on the Global Industry Classification Standard ( GICS), while the value of 0 is the opposite.

\section{Regression Model}

The multiple linear regression equation in this study can be stated as follows:

$\begin{array}{lll}\mathbf{Y}=\boldsymbol{\alpha}+\boldsymbol{\beta}_{\mathbf{1}} \mathbf{X}_{\mathbf{1}}+ & \boldsymbol{\beta}_{\mathbf{2}} \mathbf{X}_{\mathbf{2}}+\boldsymbol{\beta}_{\mathbf{3}} \mathbf{X}_{\mathbf{3}}+\mathbf{e} \\ \text { Information : } & \\ \mathrm{Y} & : & \text { Carbon } \\ & & \text { Disclosure } \\ \mathrm{A} & : & \text { Constant } \\ \beta 1, \beta 2, \beta 3 & : & \text { Regression coefficients } \\ & & \text { for each independent } \\ & & \text { variable } \\ \mathrm{X} 1 & : & \text { Media Exposure } \\ \mathrm{X} 2 & : & \text { Environmental } \\ & & \text { Performance } \\ \mathrm{X} 3 & : & \text { Industry Type } \\ \mathrm{E} & : & \text { Error } \\ & & \text { Variable) }\end{array}$

\section{RESULT AND DISCUSSION}

The object of research in this study are companies from various industrial sectors listed on the Indonesia Stock Exchange (IDX) for the 2014-2016 period. The reason for using samples with various types of industries is the limitation in disclosing carbon emissions as a criterion in selecting samples. Because in this study, the sample was focused on companies that disclose carbon emissions and the company was listed on the Indonesia Stock Exchange and followed PROPER 
Jurnal Ilmiah Akuntansi Universitas Pamulang - Vol. 7, No. 2, Juli 2019 - Ulfa \& Ermaya

ratings by the Ministry of Environment. The following table details the sample selection in this study:

Table 1. Details of Sample Selection

\begin{tabular}{|c|c|c|}
\hline No. & Company Information & Total \\
\hline 1 & $\begin{array}{l}\text { Number of Non-Financial } \\
\text { sample companies that } \\
\text { publish the Annual Report }\end{array}$ & 432 \\
\hline 2 & $\begin{array}{l}\text { Companies that do not } \\
\text { follow the PROPER ranking } \\
\text { by the Ministry of } \\
\text { Environment in 2014-2016 } \\
\text { respectively. }\end{array}$ & $(355)$ \\
\hline 3 & $\begin{array}{l}\text { Companies that do not issue } \\
\text { annual reports and } \\
\text { sustainability reports in } \\
2014-2016 \text { respectively }\end{array}$ & $(24)$ \\
\hline 4 & $\begin{array}{l}\text { Companies that do not } \\
\text { disclose information about } \\
\text { carbon emissions or } \\
\text { Greenhouse Gas emissions } \\
\text { in the Annual Report or } \\
\text { Sustainability Report } \\
\end{array}$ & $(17)$ \\
\hline \multicolumn{2}{|c|}{$\begin{array}{l}\text { The number of companies that } \\
\text { became the study sample sampel } \\
\text { penelitian }\end{array}$} & 36 \\
\hline \multicolumn{2}{|c|}{ Number of study periods } & 3 \\
\hline \multicolumn{2}{|c|}{ Number of research samples } & 108 \\
\hline
\end{tabular}

Based on the sample selection process based on the established criteria, 36 companies will be selected as samples with a period of 3 years. So that the total sample total is 108 .

Table 2.

Multiple Regression Model Test Results

Based on table. 2 regression tests above, the multiple regression equation is obtained as follows:

$\mathrm{CED}=0,057+0,207 \mathrm{MED} \_\mathrm{EXP}+0,018 \mathrm{EP}+0,052 \mathrm{TIPE}$ IND

Based on table 2, it shows the exposure media regression coefficient of 0.207 and is significant at the value of 0,000. This shows that Media Exposure has a significant effect on Carbon Emission Disclosure. 
Jurnal Ilmiah Akuntansi Universitas Pamulang - Vol. 7, No. 2, Juli 2019 - Ulfa \& Ermaya

The regression coefficient for environmental performance has a significant value of 0.18 with a significant level of 0.485 , which means that the Ho value is accepted and $\mathrm{Ha}$ is rejected, so it can be concluded that Environmental Performance has no significant effect on Carbon Emission Disclosure.

Regression coefficient value for industry type is 0.052 and a significant level is 0.130 which means that $\mathrm{Ho}$ is accepted and $\mathrm{Ha}$ is rejected, so it can be concluded that Industrial-Type has no significant effect on Carbon Emission Disclosure.

Media has an important role in communicating company information to the public, both financial performance, social aspects, and environmental aspects. The company will try to disclose information that can enhance the reputation in the eyes of the public and stakeholders. Therefore, companies that operate are not only for their own interests but also must provide benefits to their stakeholders.

Media Exposure has a significant effect on Carbon Emission Disclosure. This shows that companies that get more spotlight on their activities from online media will better show the company's good performance, especially on environmental aspects through carbon emission disclosure. This happens because of the increasing number of media reports, it will further motivate companies to make disclosures related to the environment.

The results of this study support the hypothesis that proves the effect of Media Exposure on Carbon Emission Disclosure, that the presence of media can increase disclosure of company information related to environmental aspects. This is in line with the results of research conducted by Jannah \& Muid (2014), Majid \& Ghozali (2015) and Kusumah, et al. (2016) which state that influential Media Exposure to Carbon Emission Disclosure.

This is contradictory with the results of research conducted by Cahya (2016) and Pratiwi \& Sari (2016) that media disclosure does not have a significant influence on disclosure of social and environmental responsibility because of excessive concerns regarding the company's environmental supervision if disclosed publicly media. Where it tends to bring negative public opinion towards the company if it is known that environmental control does not work optimally.

Environmental Performance Variables on Carbon Emission Disclosure in nonfinancial companies in 2014-2016 showed that the Environmental Performance variable had no significant effect on Carbon Emission Disclosure. This explains that the higher the PROPER rating received by the company does not affect carbon emission disclosure. Companies with a higher PROPER rating are more likely to not disclose carbon emissions because companies have felt their performance is good in the context of reducing carbon emissions.

The results of this study are in line with the results of research conducted by Jannah \& Muid (2014), Suhardi \& Puwanto (2015), Cahya (2016) and Majid \& Ghozali (2015) which state that Environmental Performance does not affect Carbon Emission Disclosure. Research conducted by Dawkins \& Fraas (2011) has different results, where environmental performance has a positive relationship with environmental disclosure, namely climate change. The high rating is given by PROPER (Program of Rating of Company Performance) indirectly represents the company's commitment to overcoming the problem of climate change.

* Corresponding author's e-mail: fennyaulia17@gmail.com

http://openjournal.unpam.ac.id/index.php/JIA 
Jurnal Ilmiah Akuntansi Universitas Pamulang - Vol. 7, No. 2, Juli 2019 - Ulfa \& Ermaya

Industrial type in non-financial companies in 2014-2016 shows that there is no significant influence between Industrial Types on Carbon Emission Disclosure. This shows that companies in the intensive industry produce carbon emissions such as energy, transportation, materials and utilities that do not affect the disclosure of larger carbon emissions and vice versa. Companies that intensively produce carbon emissions have not fully implemented government regulations related to reporting carbon emissions. This is possible because the rules regarding reporting on carbon emissions are a new rule in Indonesia.

The results of this study are in accordance with the results of research conducted by Luo et al (2012) and Zhang et al (2012) which state that Industrial Types do not affect Carbon Emission Disclosure. Whereas, the results of Cahya's (2016) research, Jannah \& Muid (2014) and Pratiwi \& Sari (2016) prove the influence of the industrial type on carbon emission disclosure. These results suggest that intensive companies in producing carbon often get more attention from non-intensive companies in producing carbon so companies included in this industry are required to provide voluntary disclosure reports. Therefore, disclosure by an intensive company in producing carbon will greatly assist the company in gaining legitimacy from the community and as a form of corporate responsibility towards the community.

\section{CONCLUSION}

Based on this study, the conclusions that can be obtained are that the first Media Exposure has a significant effect on Carbon Emission Disclosure, both Environmental Performance has no significant effect on Carbon Emission Disclosure and the three Industrial Types have no significant effect on Carbon Emission Disclosure. This study only uses 3 independent variables, causing the ability to explain carbon emission disclosure is still considered lacking. Subsequent research in order to add other variables and can add research models such as adding moderation variables, mediating variables, and control variables so that the results of the study are more accurate and can use different measurement methods developed by other researchers in order to increase the diversity of the results of the study.

A carbon emission disclosure index guideline must have items that are detailed and in accordance with existing conditions. The carbon emission disclosure index indicators referred to in this study are quite detailed and appropriate, but most of the carbon emission disclosure index still adopts measurements from previous research outside Indonesia so that there are several indicators that are still not in accordance with the industry conditions in Indonesia. 
Jurnal Ilmiah Akuntansi Universitas Pamulang - Vol. 7, No. 2, Juli 2019 - Marito \& Prasetya

\section{REFERENCE}

Cahya, B.T. (2016). Carbon emission disclosure: ditinjau dari media exposure, kinerja lingkungan dan karakterisitik perusahaan go public berbasis syariah di indonesia. Nizham. vol. 5, no. 2, Desember.

Deegan, C. (2002). Introduction: the legitimising effect of social and environmental disclosures a theoretical foundation. Accounting, Auditing \& Accountability Journal, vol. 15, issue: 3, pp.282-311.

Dowling, J., \& Pfeffer, J. (1975). Organizational legitimacy: social values and organizational behavior. The Pacific Sociological Review, vol. 18, no. 1.

Ghozali, I. (2013). Aplikasi analisis multivariate dengan program SPSS, Edisi ketujuh. Badan Penerbit Universitas Diponegoro (BPUD). Semarang.

Jannah, R., \& Muid, D. (2014). Analisis faktor-faktor yang mempengaruhi carbon emission disclosure pada perusahaan di Indonesia (studi empiris pada perusahaan terdaftar di bursa efek indonesia periode 2010-2012). Fakultas Ekonomika dan Bisnis, Universitas Diponegoro.

Kusumah ,R.W.R., Manurung, D.T.H., Oktari, S.D., \& Husnatarina, F. (2016). Analysis of factors affecting carbon emission disclosure (an empirical study at companies registered with sustainability reporting award 2015). 8th Widyatama International Seminar on Sustainability.

Luo, Le., Qingliang, T., Yi-chen, L. (2012). Corporate incentives to disclosure carbon information: evidence from cdp global 500 report. Journal of international financial management and Accounting, Vol. 23, No. 2.

Majid, R.A., \& Ghozali, I. (2015). Analisis faktor-faktor yang mempengaruhi pengungkapan emisi gas rumah kaca pada perusahaan di indonesia. Journal of Accounting.

Martinez, L.H. (2005). Post industrial revolution human activity and climate change: why the united states must implement mandatory limits on industrial greenhouse gas emissions. Journal Of Land Use 20, pp. 407-426.

Pratiwi, P.C., \& Sari, V.F. (2016). Pengaruh tipe industri, media exposure dan profitabilitas terhadap carbon emission disclosure. Jurnal WRA, vol.4, no.2.

Rosegrant, M.W., Ewing, M., Yohe, G., Burton, I., Huq, S., \& Santos, R.V. (2008). Climate change and agriculture: threats and opportunities 